\title{
Implementasi Multi Metode Dalam Proses Distribusi Pupuk di Desa Gerung Lombok Barat
}

\author{
Ni Ketut Sriwinarti, Wiya Suktiningsih ${ }^{1}$, Diah Supatmiwati ${ }^{2}$ \\ Jurusan Akutansi, Fakultas Ekonomi dan Bisnis, Universitas Bumigora, \\ ${ }^{1,2}$ Jurusan Sastra Inggris, Fakultas Sosial dan Humaniora, Universitas Bumigora, \\ Jl. Ismail Marzuki Karang Tapen Cakranegara - Kotak Pos No. 83239 - Mataram 83239 \\ * Penulis Korespodensi : sriwinarti@stmikbumigora.ac.id
}

\begin{abstract}
Abstrak
Kelangkaan pupuk merupakan permasalahan yang dihadapi oleh para petani secara terus menerus setiap tahunnya, meskipun pemerintah telah merubahan aturan dan sistem pendistribusian namun masih belum bisa mengatasi permasalahan yang terjadi. Keluhan dan permasalahan petani inilah yang menjadi prioritas dalam pengabdian masyarakat kali ini, pengabdian ini berupaya menerapkan sistem atau metode pendistribusian pupuk guna mengatasi permasalahan kelangkaan yang sering terjadi khususnya distribusi pupuk di bagian hilir. Metode yang diterapkan untuk mengatasi permasalahan tersebut adalah; Pemberian kartu petani sementara (sambil menunggu kartu petani resmi dari pemerintah), pembuatan sistem informasi distribusi, dan pendampingan ke petani dalam proses penanaman dan pemupukan padi (yaitu mulai dari pengolahan tanah, penanaman, pemupukan hingga panen). Berdasarkan dari hasil implementasi dan evaluasi di lapangan, metode pendistribusian pupuk ini dapat mengatasi carut marut proses distribusi pupuk sehingga pupuk dapat diberikan kepada yang berhak dan sesuai dengan jatah yang ada di RDKK. Para petani tahu kemana dia harus melapor dan mendapatkan pupuk. Walaupun masih ditemukan permasalahan seperti kesalahan data input pupuk di RDKK, data jatah pupuk tidak sesuai dengan yang dibutuhkan petani. Namun hal ini dapat diperbaiki setelah dilakukan kordinasi dengan petugas pelaksana lapangan (ppl) pertanian.
\end{abstract}

Kata Kunci: Distribusi pupuk, Kartu Petani, Kelangkaan Pupuk

\begin{abstract}
Fertilizer scarcity is a problem faced by farmers continuously every year, even though the government has changed the rules and distribution system, but it still cannot solve the problems that occur. The complaints and problems of these farmers are the priority in this community service. This community service seeks to implement a fertilizer distribution system or method to overcome the scarcity problem that often occurs, especially the distribution of fertilizers in the downstream. The methods applied to overcome these problems are; Provision of temporary farmer cards (while waiting for official farmer cards from the government), development of a distribution information system, and assistance to farmers in the process of planting and fertilizing rice (starting from land cultivation, planting, fertilizing to harvesting). Based on the results of implementation and evaluation in the field, this fertilizer distribution method can overcome the chaos of the fertilizer distribution process so that fertilizers can be given to those who are entitled and in accordance with the quota in the RDKK. The farmers know where to report and get fertilizer. Although there are still problems such as errors in fertilizer input data in RDKK, the fertilizer ration data is not in accordance with what farmers need. However, this can be improved after coordination with the agricultural field executing officer (ppl).
\end{abstract}

Keywords: Distribution of fertilizers, Farmers Cards, Fertilizer Scarcity

http://ejournal.urindo.ac.id/index.php/PAMAS

Article History :

Submitted 08 Januari 2021, Accepted 26 Oktober 2021, Published 31 Oktober 2021 


\section{PENDAHULUAN}

Pasca gempa 2018, kini harus menghadapi pandemi covid-19, hal tersebut memukul kembali perekonomian NTB. Data Badan Pusat Statistik (BPS) Nusa Tenggara Barat menunjukkan bahwa pada tahun 2019 pertumbuhan ekonomi NTB mengalami pertumbuhan positif apabila dibandingkan dengan tahun sebelumnya yaitu dari 6,13 persen di tahun 2018 menjadi 8,63 persen pada tahun 2019. Namun pada tahun 2020 pertumbuhan ekonomi NTB hanya 3,19 persen mengalami kontraksi sebesar 5,44 persen dari tahun sebelumnya. Sektor yang menjadi penyelamat perekonomian NTB adalah Sektor pertanian, kehutanan, dan perikanan. Sektor pertanian senantiasa selalu menjadi andalan provinsi Nusa Tenggara Barat (NTB) khususnya dalam mempertahankan laju pertumbuhan ekonomi di masa pandemi saat ini. Hal ini sejalan dengan apa yang disampaikan oleh Menteri Pertanian Bapak Syahrul Yasin Limpo yang mengungkapkan bahwa di masa pandemi Covid-19, sektor pertanian masih tumbuh positif. Bahkan menjadi satu-satunya sektor penyelamat perekonomian nasional. "Panen padi menjadi pembuktian bahwa dalam tantangan apa pun, pertanian selalu berproduksi" (Post 2021).

Tabel 1

Perbandingan Luas Lahan untuk Tanaman Padi

\begin{tabular}{|c|l|r|r|r|}
\hline No & \multicolumn{1}{|c|}{ Kabupaten/kota } & $\begin{array}{c}\text { Luas Area } \\
\text { (ha) }\end{array}$ & $\begin{array}{c}\text { Luas Panen } \\
\text { Padi Tahun } \\
2020 \text { (ha) }\end{array}$ & persentase \\
\hline & & & & $24 \%$ \\
\hline 1 & Lombok Barat & 105,392 & 25,659 & $59 \%$ \\
\hline 2 & Lombok Tengah & 120,840 & 71,692 & $29 \%$ \\
\hline 3 & Lombok Timur & 160,555 & 46,674 & $8 \%$ \\
\hline 4 & Sumbawa & 664,398 & 51,234 & $8 \%$ \\
\hline 5 & Dompu & 232,460 & 18,408 & $6 \%$ \\
\hline 6 & Bima & 438,940 & 36,556 & $6 \%$ \\
\hline 7 & Sumbawa Barat & 184,902 & 11,795 & $40 \%$ \\
\hline 8 & Lombok Utara & 80,953 & 4,789 & $14 \%$ \\
\hline 9 & Kota Mataram & 6,130 & 2,467 & $14 \%$ \\
\hline 10 & Kota Bima & $2,015,320$ & 272,193 & \\
\hline \multicolumn{1}{|c|}{ Secara Keseluruhan } & & & \\
\hline
\end{tabular}

Sumber : Kanwil Badan Pertanahan Nasional Provinsi NTB 2018-2020 (Badan Pusat Statistik 2018)

Merujuk pada tabel 1, diketahui bahwa secara keseluruhan, lahan yang dijadikan untuk pertanian cukuplah luas yaitu mencapai $14 \%$ dari total luas area di provinsi Nusa Tenggara Barat (NTB) sedangkan apabila kita merujuk ke masing-masing kabupaten maka terlihat bahwa Kota Mataram, Kabupaten Lombok Tengah, Kabupaten Lombok Timur dan Kabupaten Lombok Barat memiliki lahan tanam padi di atas $20 \%$ dari seluruh total luas area, dan khusus untuk wilayah kabupaten lombok tengah malah lebih dari 50\% luas area dijadikan lahan pertanian. Data tersebut menunjukkan bahwasanya sektor pertanian menjadi komoditas utama yang paling berpengaruh terhadap perekonomian masyarakat NTB, sehingga sudah sewajarnya jika pemerintah daerah diminta untuk lebih dapat memperhatikan kepentingan para petani. 
Sektor pertanian selalu jadi andalan tetapi kelangkaan pupuk menjadi permasalahan utama dan klasik yang dihadapi oleh para petani setiap musim tanam. Setiap awal musim tanam terjadi secara tibatiba pupuk seolah menghilang, padahal pupuk memiliki peranan penting dalam peningkatan produksi dan produktivitas pertanian. Hasil produksi tidak akan dapat mencapai angka yang maksimal jika petani terlambat memberikan pupuk secara tepat dan benar. Pemerintah pada dasarnya sangat mengetahui permasalahan pentingnya pupuk bagi petani. Namun permasalahaan kelangkaan tersebut sampai saat ini masih menjadi masalah utama di awal musim tanam. Transformasi aturan dan metode telah dilakukan namun tetap saja permasalahan ini tetap tidak bisa terselesaikan. Dari uraian permasalahan mitra tersebut, tim pengabdian melakukan kegiatan pengabdian dalam bentuk penerapan sistem informasi distribusi pupuk dengan menerapkan kartu petani hingga membantu mendata kebutuhan pupuk berdasarkan RDKK (Rencana Definitif Kebutuhan Kelompok). Sistem informasi ini akan merekam data petani yang ada dikartu petani, dimana kartu petani berisi informasi data petani dan data luas lahan pertaniannya, dari data tersebut bisa diketahui jatah pupuk yang bisa diambil oleh petani tersebut. Sehingga pendistribusian pupuk tepat sasaran dan sesuai kuota. Setelah petani mendapatkan jatah pupuknya tim pengabdian akan melakukan pendamping ke petani untuk penggunaan pupuk secara efisien dilapangan. Hal ini dilakukan guna mendapatkan informasi apakah pupuk yang diberikan kepada petani itu benar dan apakah takaran yang diberikan oleh petugas sudah tepat. Di akhir pengabdian diharapkan agar para petani sudah memiliki kepastian bahwa dirinya memiliki jatah pupuk yang benar dan kemana harus nebus sehingga para petani tidak harus merasa takut setiap awal musim tanam.

\section{METODE}

Solusi Yang ditawarkan pada kegiatan PKM ini adalah penerapan sistem distribusi pupuk dan pendampingan ke petani ini sebagai solusi dari permasalahan yang dihadapi oleh mitra. Penekanan yang dilakukan adalah pada saat penyaluran pupuk yang langsung diterima oleh petani. Cara atau mekanisme yang ditawarkan yaitu memperkenalkan pentingnya penggunaan kartu kendali yang digunakan sebagai tanda pengenal pemilik pupuk, di mana setiap petani membawa kartunya untuk melakukan penebusan. Sedangkan di pihak pengecer akan terdapat/memiliki sebuah sistem informasi yang berisi informasi mengenai berapa jumlah limit pupuk permasing-masing petani sesuai dengan RDKK yang di berikan oleh masing-masing gapoktan. Selain itu sistem ini akan secara otomatis menghitung sisa kuota atau jatah pupuk pada petani setiap penebusan yang dilakukan. Sedangkan solusi mengenai ketepatan data adalah tim pengabdi akan ikut pendampingi dalam proses penanaman hingga pemberian pupuk pada lahan petani yang ditunjuk.

\section{Prosedur Kerja}




\section{Tahap Pengenalan dan implementasi sistem Informasi Distribusi Pupuk}

Pada prinsipnya metode yang digunakan dalam penerapan kartu kendali distribusi pupuk ini adalah dengan menggunakan ceramah,demonstrasi/peragaan dan uji coba langsung atau jika dijabarkan akan sebagai berikut: (a)Tahap persiapan yaitu tim pengabdian akan berkordinasi dengan pengecer resmi yang akan dijadikan lokasi pengabdian; (b)Tahap instalasi yaitu menginstal aplikasi sistem informasi distribusi pupuk pada komputer yang ada di pengecer resmi dan menginputkan data terbaru berdasarkan RDKK; (c)Tahap uji coba yaitu tahapan ini terdiri atas dua bagian, pada bagian pertama pengabdiakan menguji kesiapan sistem yang telah terinstal, sedangkan pada bagian dua pengabdiakan melatih staf bagian penginputan data; dan (d)Tahap pengenalan kartu ke petani.

\section{Tahap Pendampingan dalam Penggunaan Pupuk di Lapangan}

Tahapan kerja ini dilakukan untuk memberi pemahaman dan keyakinan kepada para petani dan petugas lapangan berkaitan jumlah jatah pupuk yang ada di RDKK apakah telah sesuai atau tidak. Berikut adalah tahapan yang dilakukan team: (a) Persiapan yaitu tahapan dimana tim pengabdi akan berkordinasi dengan Ketua Kelompok Tani berkaitan para petani yang terlibat dan lahan persawahan yang akan dijadikan lokasi pengabdian dibutuhkan masing-masing 2(dua) petani dari masing-masing mitra untuk dapat bekerja sama dari awal hingga panen; (b) Tahap Olah Tanah yaitu tahapan yang terdiri atas tahap pembersihan lahan, pembajakkan, dan Pengairan; (c) Tahap Pembibitan, pada tahapan ini terdapat 2 (dua) varietas yang akan di tanam, satu akan diserahkan sesuai dengan pilihan petani sedangkan satu lahan lagi berdasarkan pilihan pengabdi yaitu inpari 27/31; (d) Tahap Penanaman, Metode tanam yang dilakukan yaitu sistem Jajar Legowo 4:1 dan 5:1, metode tanam ini sengaja team pengabdi pilih berdasarkan pengalaman tahun lalu yang menunjukkan hasil gabah yang lebih signifikan; (e) Tahap Pemupukan dan Pengobatan yaitu tahapan utama dilakukan pemupukan sesuai dengan takar yang telah ditetapkan dalam RDKK sesuai dengan musim tanam dan luas tanah; (f) Tahap Panen yaitu tahap penilaian hasil yang diterima apakah sesuai dengan yang diharapkan atau tidak.

\section{HASIL DAN PEMBAHASAN}

Pengabdian ini dilaksanakan pada bulan Maret sampai Juli 2020 bertempat di wilayah Lombok Barat, tepatnya dusun Reyan Kecamatan Gerung. Hasil dari pengabdian ini walaupun tidak menjawab seluruh permasalahan yang ada, setidaknya ada perubahan sistem yang mampu mengurai keruwetan distibusi pupuk di wilayah Lombok Barat. Pertama, kegiatan pengabdian ini menjabarkan dan menjelaskan bagaimana fungsi dan sistem kerja dari kartu petani sementara yang telah dibagikan.

Tahap pertama ini memerlukan waktu satu bulan, untuk memberikan penjelasan dan membantu dalam proses distribusi pupuk ke 47 orang petani dari 299 orang petani yang terdaftar di 
mitra serta menjelaskan mengenai hak mereka dan batas atau jatah pengguaan pupuk. Jumlah ini lebih sedikit bila dibandingkan dengan tahun lalu dikarenakan pandemi sehingga tim pengabdi terpaksa membatasi ruang gerak demi menjaga kesehatan dan keamanan bersama.

Berdasarkan penjabaran di atas, fenomena tersebut muncul dikarenakan adanya rasa aman dan terjamin yang dirasakan oleh para petani. Pertanyaan yang muncul adalah bagaimana tahap hingga rasa aman dan terjamin pada para petani tersebut muncul, maka berikut akan dijabarkan tahapan yang telah pengabdi lakukan: Langkah pertama yang pengabdi lakukan adalah melakukan instalasi sistem informasi pada unit komputer yang telah terpasang pada mitra, selain melakukan instalasi, tim PKM juga memberikan gambaran mengenai menu-menu yang tersedia dalam aplikasi. Diawali dengan mempraktekkan secara langsung bagaimana menginput data petani, dan cara memproses data pada saat penebusan, dan di akhiri bagaimana menginput penjualan pupuk hingga mencetak laporan disetiap akhir kegiatan yang bisa dilihat dalam rentang waktu per-bulan ataupun pertahun.

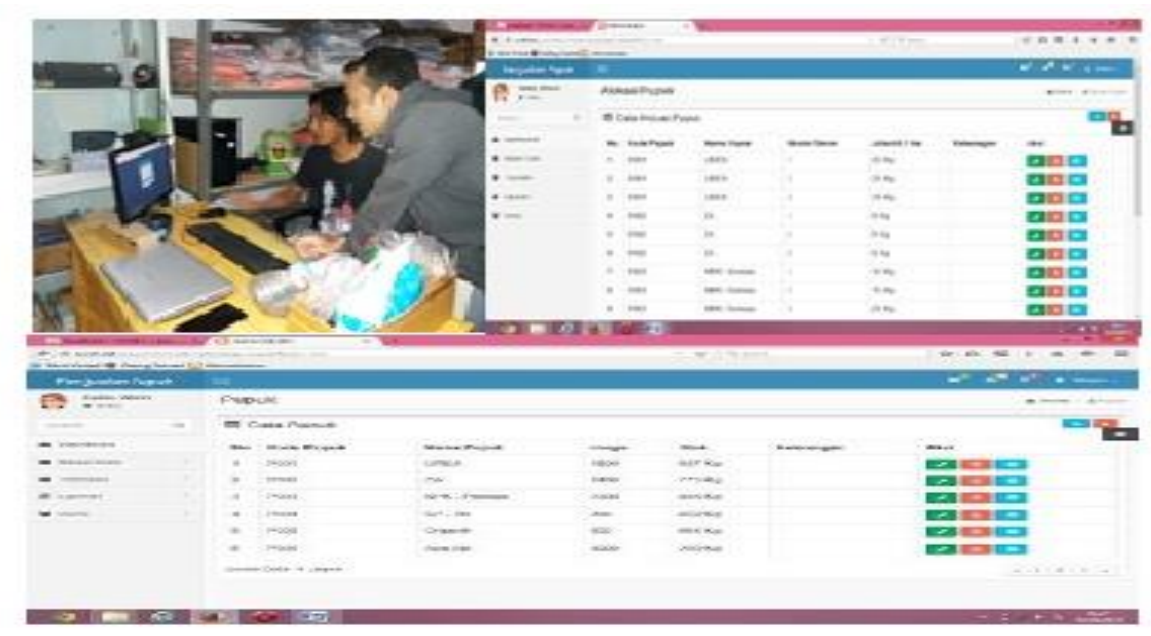

Gambar 1. Foto Saat instalasi aplikasi dan Layout pupuk

Menu-menu utama yang tersedia pada aplikasi sistem informasi pupuk ini yaitu salah satunya mengatur mengenai jumlah pupuk yang dibagikan ke petani. Jumlah yang dibagikan telah ditetapkan oleh pengawas lapangan, yaitu berdasarkan luas tanah dan berdasarkan musim tanam.

Tabel 2

.Alokasi Pupuk

Jumlah Yang Dibutuhkan per 0,1 Ha

\begin{tabular}{ccc} 
Nama Pupuk & \multicolumn{2}{c}{$(10$ are $=1000 \mathrm{~m} 2)$} \\
\cline { 2 - 3 } & $\begin{array}{c}\text { Musim Tanam 1 } \\
\text { dan 2 }\end{array}$ & Musim Tanam 3 \\
\hline UREA & $20 \mathrm{~kg}$ & $30 \mathrm{~kg}$ \\
\hline SP-36 & $10 \mathrm{~kg}$ & $10 \mathrm{~kg}$ \\
\hline ZA & $5 \mathrm{~kg}$ & $5 \mathrm{~kg}$ \\
\hline NPK & $10 \mathrm{~kg}$ & $20 \mathrm{~kg}$ \\
\hline Organik & $50 \mathrm{~kg}$ & $50 \mathrm{~kg}$ \\
\hline
\end{tabular}


Sistem ini dirancang pembagian (penjatahan) pupuk ke masing-masing petani adalah sesuai dengan kepemilikan tanah yang dimiliki yaitu misalkan luas tanah di lini pengecer mengenai berapa seharusnya hak pupuk yang seharusnya diberikan untuk masing-masing petani.

Langkah kedua yang tim PKM lakukan adalah membagikan kartu petani sementara. Pada perencanaan awal, kegiatan ini akan menggunakan kartu petani yang akan langsung dibagikan oleh pemerintah, namun sampai kegiatan pengabdian ini dilakukan, penyediaan kartu petani dari pemerintah seperti yang direncanakan tidak datang sehingga tim menggunakan rancangan sementara yang pernah tim gunakan pada kegiatan sebelumnya, dan mencetak kartu sejumlah 299 buah kartu (sesuai dengan data baru yang diberikan oleh mitra kelompok petani desa Reyan)

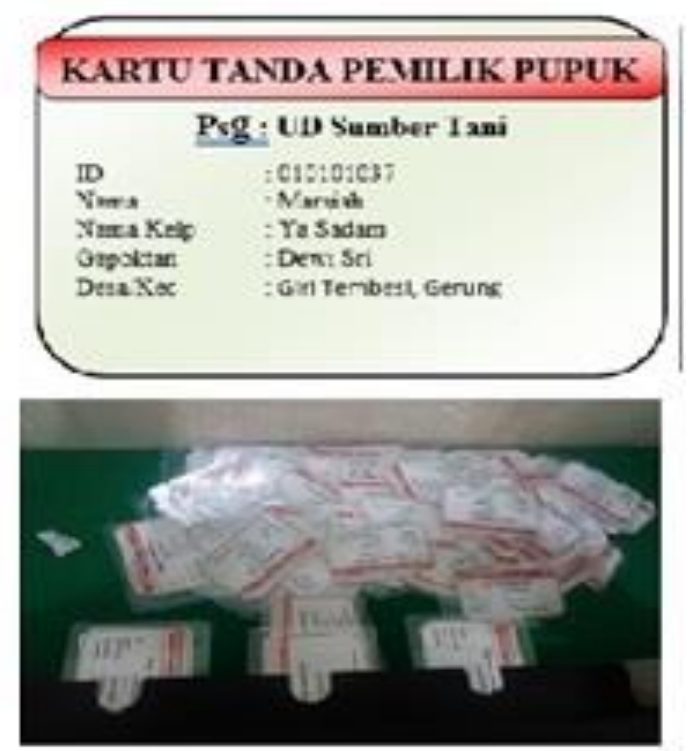

Gambar 2. Kartu Petani Sementara

Langkah ketiga adalah proses pendampingan dalam proses pemberian pupuk untuk melihat apakah pupuk yang diinputkan sesuai dengan apa yang dijatahkan oleh petugas lapangan namun pada Langkah ini ternyata memakan waktu yang jauh lebih panjang dan team pengabdi menjadi terlibat secara penuh dalam proses kehidupan padi menjadi beras.

"Menyatulah dengan tanaman, maka engkau akan tahu apa yang harus dilakukan"

Ungkapan diatas merupakan kata-kata yang selalu diucapkan oleh Bapak Harun, beliau adalah seorang pensiunan pegawai negeri sipil yang kini berprofesi menjadi petani, menurut beliau semua hal bisa dipelajari tapi yang terpenting adalah bagaimana hati anda ikut berada di apa yang anda kerjakan. Padi merupakan makhluk hidup sehingga baik atau tidaknya kita merawat akan berdampak pada pertumbuhan dan hasil yang nantinya akan diperoleh. Musim pertama merupakan musim yang sangat 
baik buat menanam padi karena pada saat itu masih musim hujan sehingga air sangat melimpah, tanah pun sangat cocok untuk ditanamin padi karena sebelumnya telah ditanami palawija yang membuat kadar ph tanah kembali normal. Namun alam seperti tak bersahabat, disaat pandemi hujan pun tak kunjung datang sehingga musim tanam pun tertunda karena keberadaan air yang terbatas. Semangat juang para mitra yang sangat mencintai pekerjaannya telah menginspirasi tim PKM, sehingga disini tim ikut belajar bersama-sama dengan mitra bagaimana menanam hingga menghasilkan beras terdapat 2 (dua) lahan yang pengabdi lakukan pengabdian, ada yang terlibat langsung dari awal hingga akhir ada yang pengabdi hanya lakukan pendampingan saja. Lahan yang pengabdi terlibat langsung adalah lahan bersama bapak Harun yaitu seluas 52 are dan lahan bersama Bapak Sarke seluas 47 are.

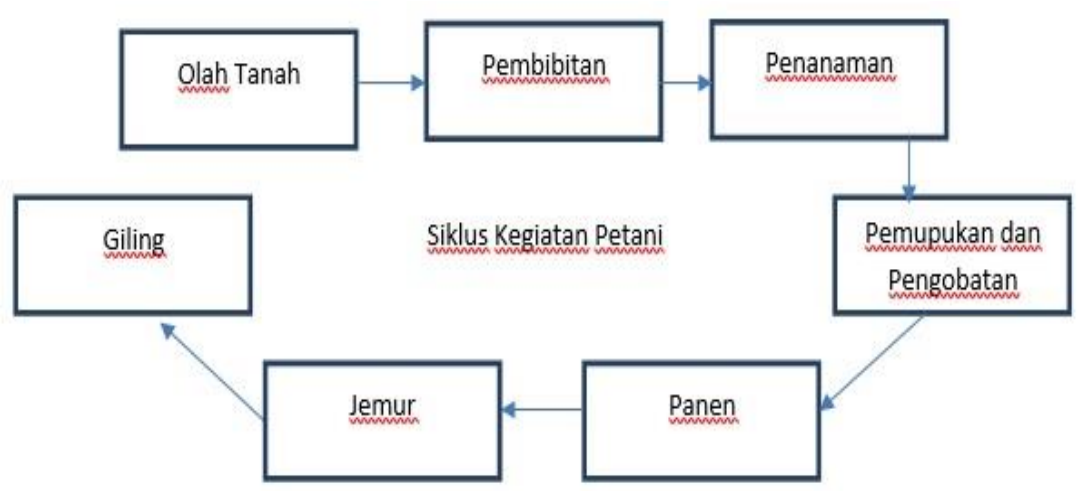

Gambar 3. Siklus Kegiatan Petani

Mulai dari benih kemudian menjadi padi, dan padi mendapatkan gabah, dari gabah kemudian menjadi beras adalah proses yang cukup panjang dan butuh perhatian. Didalam perjalannnya terkadang diketemukan permasalahan yang unik dan mendebarkan, mulai dari hujan yang tiba-tiba menghilang, harus menunggu jam 2 pagi agar mendapatkan jatah irigasi, serangan hama dan jatah pupuk yang kurang.

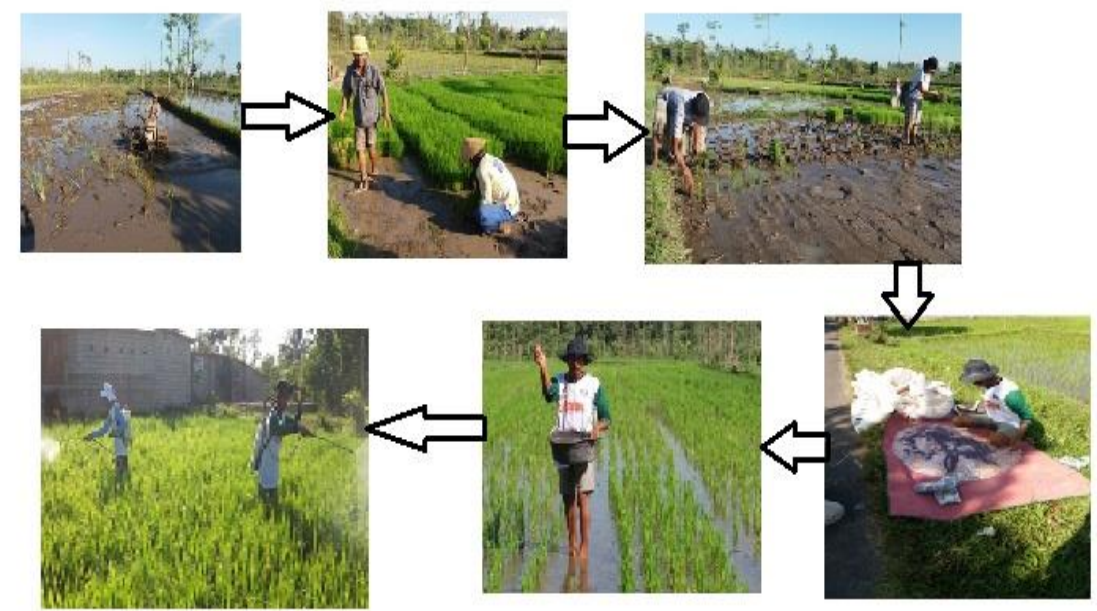

Gambar 4. Foto kegiatan Awal Musim Tani 
Pada proses olah tanah, para petani sudah banyak memilih menggunakan alat bajak dikarenakan apabila menggunakan sapi/kerbau, selain jarang juga waktu dan hasil yang diperoleh kurang optimal.

Cara tanam yang dipilih adalah dengan jajar legowo. Metode ini merupakan salah satu teknologi yang dapat meningkatkan populasi tanaman per satuan luas yang diharapkan secara signifikan meningkatkan produktivitas padi sawah (Badan Litbang Pertanian, 2009).

Sistem tanam legowo pada prinsipnya memanipulasi tata letak tanaman sehingga sebagian besar tanaman menjadi tanaman pinggir(Kartika et al. 2018). Sistem tanam jajar legowo dikembangkan dari sistem tanam tegel yang telah berkembang di Masyarakat(Ikhwani et al. 2015). Menurut (Wang et al. 2013) efek pinggir memberikan pengaruh terhadap lebih tingginya produksi biomassa, lebih banyaknya malai per satuan luas dan lebih tingginya persentase gabah isi. Pak Busro yang merupakan petugas pertanian juga menjelaskan bahwasanya dengan adanya jarak juga sangat memudahkan ketika pemberian pupuk dan obat-obatan.

Pemupukan dilakukan sebanyak 2 (dua) kali yaitu pertama dilakukan setelah 15 hari dari penanaman, pemberian pupuk ini merupakan hal yang sangat penting dalam membantu pertumbuhan padi sedangkan pemupukan kedua dalam istilah para petani adalah pupuk "balas" yang artinya pupuk pelengkap untuk tanaman padi yang apabila pertumbuhannya tidak rata. Ketidakrataan pertumbuhan tersebut biasanya disebabkan karena pada saat awal pupuk tidak terkena atau mendapatkan pupuk lebih sedikit. Pemupukan kedua dilakukan setelah 25 hari dari pemupukan pertama.Pada saat pemupukan kedua, selain masalah ketersediaan pupuk, permasalahan air menjadi permasalahan lain yang dihadapi oleh para petani, dimana musim kemarau terlalu awal untuk tahun ini sehingga proses pemupukan kedua menjadi tertunda.
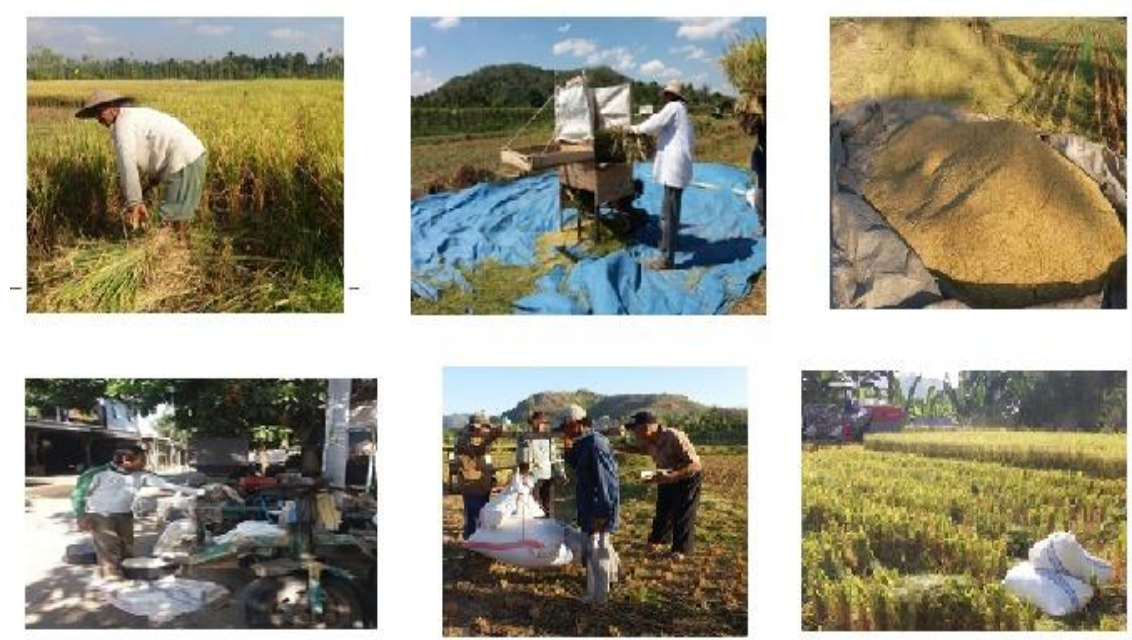

Gambar 5. Foto kegiatan Menjelang Musim Panen 
Walaupun terdapat beberapa kendala dilapangan namun peserta tidak mengalami gagal panen, akan tetapi karena keterlambatan dalam pemberian pupuk sehingga mengakibatkan hasil gabah yang kurang optimal bila dibandingan tahun lalu.

\section{PENUTUP}

Satu hal yang tim pengabdi temukan dilapangan sebagai bagian dari permasalahan kelangkaan pupuk adalah komunikasi dan penginputan data yang tidak tepat pada saat menerbitkan RDKK, data jatah pupuk juga tidak bisa konsisten setiap tahun diakibatkan karena perubahan dari penggarap tanah. Kebanyakkan petani ternyata mengerjakan lahan sewaan sehingga lahan yang sama bisa jadi petani yang berbeda. Selain itu takaran yang diberikan oleh petugas lapangan tidak sesuai dengan kebutuhan petani karena sedikit banyakknya kebutuhan pupuk petani adalah tergantungdari factor cuaca dan kandungan ph tanah.

Ada hal yang masih menjadi beban bagi tim pengabdi yang dirasakan setiap akhir dalam pelaksanaan pengabdian, ketika suatu metode dirasakan berhasil untuk membantu mengatasi permasalahan dilapangan namun ternyata perubahan aturan dan rumitnya birokasi membuat permasalahn baru dialami dan setiap kali ada perubahan, pihak yang di rugikan selalu kembali adalah petani.

\section{UCAPAN TERIMAKASIH}

Ucapan terima kasih ditujukan kepada kelompok petani dusun Reyan kecamatan Gerung Lombok Barat.

\section{DAFTAR RUJUKAN}

1. Badan Pusat Statistik. 2018. "Badan Pusat Statistik Nusa Tenggara Barat." (2): 131. https://ntb.bps.go.id/indicator/53/334/1/luas-panen-produksi-dan-produktivitas-padi-hasilksa.html.

2. Instruksi Presiden Republik Indonesia Nomor 3 Tahun 1999 Tentang Pembaharuan Kebijaksanaan Pengelolaan Irigasi

3. Ikhwani, Gagad Restu Pratiwi, Eman Paturrohman, and A K Makarim. 2015. "Peningkatan Produktivitas Padi Melalui Penerapan Jarak Tanam Jajar Legowo." Iptek Tanaman Pangan 8(2): 7279. http://pangan.litbang.pertanian.go.id/files/03-lkhwanilT0802.pdf.

4. Kartika, Kartika et al. 2018. "Internal versus Edge Row Comparison in Jajar Legowo 4:1 Rice Planting Pattern at Different Frequency of Fertilizer Applications." Agrivita 40(2): 222-32.

5. Post, Lombok. 2021. "Perekonomian NTB Tertolong Sektor Pertanian." : 2020-21. https://lombokpost.jawapos.com/ekonomi-bisnis/07/05/2020/perekonomian-ntb-tertolong- 
Jurnal Pelayanan dan Pengabdian Masyarakat (PAMAS)

sektor-pertanian/.

6. Sriwinarti, Ni Ketut, 2016, Implementasi Penggunaan Kartu Petani: Sebagai Media Pengendali Distribusi Pupuk Bersubsidi, Proseding Seminar Nasional Teknologi Informasi dan Aplikasi (SENTIA), Vol 8 A191-195, Politeknik Negeri Malang.

7. Wang, Kai et al. 2013. "Kai Wang." 44(0): 47-54. http://www.sciencedirect.com/science/article/pii/S037842901200384X. 